日本臨床麻酔学会第 37 回大会特別企画

日臨麻会誌 Vol.39 No.1, 87 90, 2019

はじめての臨床研究 : 立案〜データを読み解くまで

研究テーマと出会うために

江木盛時*

[要旨］臨床研究のテーマに出会うには, 日頃から疑問を持ちながら診療を行う必要がある. 施設 独自のルールや予測指示などは, その正当性を過去の論文や教科書で調べることで, 研究テーマに 出会うきっかけになり得る．診療ガイドラインは，診療に不慣れな医療者に対する道標であると同 時に, いまだわかっていないことがある領域を示したリストでもあり, 今後の研究が必要な分野を 示している. また, 症例報告は $n=1$ の臨床研究でもあり, 患者さんから得た経験や知識を体系化 していく過程で, 臨床研究のテーマに出会うこともまれではない. 本稿では, 臨床研究のテーマに 出会うための方法をいくつか紹介する.

キーワード : 研究のテーマ, 臨床研究, 臨床的疑問

\section{I＼cjkstart臨床研究のテーマはどこにある？}

臨床研究の題材は日常の診療の中にあるといわれ る。しかし, 実際に日常診療の中で臨床研究のテー マに出会うことは難しいことである。学会での発表 点数獲得など, 研究を行うための動機はさまざまで はあるが，“研究するために疑問を生み出す”ので はなく, “自身が抱いた疑問を解決しょうとして研 究する”のであり，目的と行為が逆転しないように

しておく必要がある。

日常診療を続けていると，いつも同じことが繰り 返されているように感じてしまい, 普段の診療の中 に臨床研究のテーマはもはや存在しないように感じ てしまう方もいるかもしれない. 臨床研究のテーマ に出会うには, 日常の診療に際して, いつも疑問を 持ちながら行い，その疑問を過去の論文や教科書で 調べることを繰り返すことが重要である。実際に，
研究を立案し, 論文化を行っている研究者の中で過 去の論文や教科書的な記載に精通していない方は極 めて少ない，あるいは，いないのではないだろうか. あるテーマに関してきちんと知識を積み上げ，わか っていること，わかっていないことの仕分けができ ていることが, 研究テーマに出会うための鍵ではな いかと思われる。本稿では, 臨床研究のテーマに出 会うためのいくつかの方法を紹介する。

\section{II 各国, 各地域, 各病院で独特の診療}

新しく赴任した病院で，その病院特有の診療を経 験したことがある方は多いのではないだろうか. ま た，長く同じ病院に勤めていると，新しく赴任して きた先生に“病院のしきたり”を教えたことがある 方は多いのではないだろうか. 医療のWorld standard化やグローバル化が進められる現在, このよ うな独特の診療は否定的に扱われるときもある。し 
かし，その独特の診療が，普遍的な内容ではなく， 今まで聞いたことがない方法や理論であった場合に は，うのみにするのでもなく，また，頭ごなしに否 定するのでもなく, 過去の論文や教科書でその内容 を調べてみる必要があるのではないだろうか.もし， その内容が，実は普遍的な内容であった場合は，自 身の勉強不足で知らなかっただけであり, 新しい知 識を得る機会となる。これは，自身にとつても大変 良いことであるし，今後は同僚や後輩に伝えていく べき知識や技術となる。しかし, 過去の論文や教科 書にも記載されていない場合も時にある。この内容 は，もしかすると大変よい臨床研究のテーマである かもしれない。 また，世界に向けて発信すべき素晴 らしい治療や知識であるかもしれない。

郷に入れば郷に従えという言葉があるように，病 院特有の治療やお作法に慣れ親しむことも大事であ るが，一度きちんと調べてみることが，臨床研究の テーマとの出会いになることは多いはずである。各 国, 各地域, 各病院で独特の診療は, 多く存在する. 知識の確立のためにも一度きちんと勉強してみる姿 勢は重要であり, やはり臨床現場は研究テーマの宝 庫である。

\section{III 予測指示の有効性，閾值の正当性}

予測指示は，ベッドサイドに医師がいない状態で 行われている医療であり, 盲目的治療の一つである. 術後の血圧低下, 発熱時, 疼痛発生時, 嘔気嘔吐発 生時など予測指示は日常的に存在する.予測指示は, 多くの場合 “患者がある状態になったら，処置 A を行う”という定型文で作成されている，看護師が 責任医師への確認の手間を省いて処置が開始できる ため予測指示を好んで使用する施設もある。果たし てこの処置は患者に有益に作用しているのであろう か？ 副作用は生じていないのであろうか？ 治療 のトリガーとなる状態は適切に選択されているので あろうか? これらの内容を, 過去の論文や教科書 で根拠があるのか調べてみると良いかもしれない.
また，術後処置の施行率，有効率，無効であった時 にどのような処置が行われているか，有害事象発生 率などを知ることで, 新しい臨床研究テーマとの出 会いが生まれることもまれではない.このようにす べての患者で一様に行っている治療こそ臨床研究の 題材になりうるのかもしれない.

\section{IV 診療ガイドラインは, 臨床研究テーマのバイブルである}

診療ガイドラインを臨床実践のバイブルのように 勘違いして，すべての推奨を確実に行うことが良い 医療と考える方がいるかもしれない。ガイドライン において，その使用が弱く推奨されている治療を絶 対的治療のように主張する医療者や, 使用しないこ とを弱く推奨されている治療を “悪”のごとくに否 定する医療者に出会ったことはないだろうか。これ はガイドラインに医療者が操られている “ガイドラ インの悪用”であり，正しいガイドラインの使用方 法ではないと思われる。臨床研究におけるエビデン スは，統計を使用した確率論であり，患者に益ある いは害が生じる可能性(確率)を示している。ある診 療行為に不慣れな医療者が盲目的に医療を行わざる を得ない状況では，明らかに間違った判断を避け患 者予後を改善するためにより確率の高い方法を選択 するためには，ガイドラインは有用かもしれない。 すなわち，不慣れな医療者でもガイドラインを使用 することで相応の治療成績を担保することが可能と なるといえる。しかし，ガイドラインの推奨は，さ まざまなエビデンスグレードを基に作成されてい る。エビデンスグレードの低い根拠を基に作成され た推奨はその確信度が低く，いまだ決定的なエビデ ンスが存在しないといえる。また，エビデンスが存 在しないため，エキスパートの意見を利用して推奨 を提示している項目もある。このように，ガイドラ インに推奨の提示はあるものの, 今後も研究を行わ なければならない領域は多くある。具体的には，ガ イドラインにおいて低いエビデンスグレードで推奨 
が作成された領域，あるいは，エキスパートの意見 で推奨が提示された領域では, その傾向が強くなる. 上記のごとく, 今後の臨床研究の必要性を示すとい う役割も担っていると考えれば，ガイドラインは臨 床研究のテーマのバイブルでもある.

\section{$\mathrm{V}$ 症例報告は $\mathrm{n}=1$ の臨床研究}

医師であれば，目の前にいる患者を助けたいと思 うのは当然のことである。その真摰な治療の中で考 慮した治療や着目した患者情報に関して，1)教科書 的に知られているものとは異なる所見，2)治療に対 する異常な有害反応，3)他の疾病と似通っているた めに誤診につながる症状，4) 新しい対処法・治療法, そして5)珍しい疾患や疾病があれば, 過去の論文 や教科書で調べてみる必要がある。その際に, 新し い事実や発見があれば症例報告をすると良い。症例 報告を行うためには, 患者情報や治療経過を科学的 に検討する必要がある。また，考察を行うために多 くの文献を読む必要がある。したがって, 症例報告 は $\mathrm{n}=1$ の臨床研究と言つても差し支えない. 出会 つた患者さんから得た経験や知識を体系化していく
過程は臨床医が成長する上での栄養素であり，また その過程の中で臨床研究のテーマに出会うことはま れではない。症例報告は，同様な患者を他の医療者 が診療を行う際に，患者を救う一助となる可能性が あるため重要である。また，同時に，ケースレポー トを執筆できるほど日常の診療を真摰に行っている 医療者ほど, 臨床研究のテーマを日常の診療の中で 発見できるのかもしれない.

\section{まとめ}

研究テーマとの出会いは, 日常診療の中に存在す る.同時に日常診療の中に存在しない研究テーマ(臨 床的疑問) は, 研究しょうと思っても, 対象患者が 存在しないため, 研究の遂行ができない. 日々の診 療の中で, わからないことを調べ整理していくこと が重要であり，その過程の中で，今までは空気のよ うに感じていて気が付かなかった研究テーマに気が 付くようになるのではないだろうか. 各病院での独 特の診療, 予測指示, ガイドライン, 症例報告はそ のきっかけの一つになると考えられる。 


\title{
How to Meet with Promising Research Themes
}

\author{
Moritoki EGI \\ Department of Anesthesiology, Kobe University Hospital
}

\begin{abstract}
In order to meet with promising clinical research themes, it is critical for clinicians to remain vigilant in their day-to-day clinical practices and questions. By looking for the rationales behind their institution's own rules and practices using the literature and textbooks, they may find good research themes. Therapeutic guidelines serve as useful maps for unexperienced clinicians and may indicate areas where many things remain unclear or unknown and further studies are needed. Case reports are written as a result of scientific consideration of individual patients. With such a scientific and systematic approach to the information obtained from each patient, clinicians often encounter good clinical research themes. This article presents a number of methods that can be used to meet with interesting clinical research themes.
\end{abstract}

Key Words : Research themes, Clinical research, Research question

The Journal of Japan Society for Clinical Anesthesia Vol.39 No.1, 2019 